\title{
Introduction
}

\section{Interdiction at the Expense of Human Rights: A Long-term Containment Strategy}

\author{
Janet Dench and François Crépeau
}

$\mathrm{M}$ igratory pressure is heavy around the globe and the available data does not indicate any decrease in the foreseeable future. It has always been there: the highest number of immigrants to have come to Canada in one single year is still that of 1913, with more than 400,000 . Today, globalization has only increased independent intercontinental migration. Fast and cheap transportation is available, as is international communication, through telephone and internet; knowledge about host countries is circulating through television and videos; large communities exist in host countries and are able to help friends, family, and compatriots.

The increase in global migrations also results from the fact that the differences in peace and prosperity have been sharpened between North and South in the past decades. Many societies in the South have become poorer and messier: some people need to escape increasing violence; others seek better survival opportunities for themselves and their children. The increase in these "push factors" is a negative dimension of globalization.

In most host countries, the protection and promotion of rights and freedoms have been reinforced. Constitutional, regional, and international standards are more sophisticated, and implementation mechanisms are more effective. We now know that the interaction of political struggle and legal jurisprudence is key to effectively protecting human rights: the European Court of Human Rights, the InterAmerican Commission, the UN committees, the constitutional case law in, say, Canada, Germany, and South Africa testify that there is also a globalization phenomenon in the field of human rights. In host countries, this case law will often protect the foreigner and declare that she is equal to the citizen on most issues regarding fundamental rights.
But our States nowadays often feel dispossessed in a field that has been at the basis of their legitimacy for the past decades: redistribution of wealth and social justice. This goal is challenged by yet another aspect of globalization: essentially free-trade policies and the pressure that economic actors exercise to lower the cost of production. Our States have tried to regain political ground by insisting on their traditional mission since the Renaissance: security. In the past twenty years, a phenomenon of "securization" of the public sphere has emerged and resulted in the definition of new fields of government activity: food security, environmental security, bio-security, transport security, industrial security, internal security, migration security, to name only a few.

States have re-emphasized the role of the border as the traditional and tangible symbol of their power. This is not a new phenomenon. The border has always been used to distinguish between "us" and "them." For example, in the aftermath of World War I, the Canadian government responded to the arrival of impoverished and displaced Europeans by tightening the laws and stationing immigration officials at ports in Europe to prevent further "undesirables" from setting sail.

Following the sharp increase in asylum claims in the mid-1980s, States have launched a huge co-operative effort aimed at controlling migration flows, and in particular reducing irregular flows. This effort targeted especially asylum seekers, because, as these could count on human rights standards and mechanisms to argue against refoulement, host States knew there was a good chance that they would not be able to remove them from the territory.

This co-operation was particularly productive in Europe, as the abolition of the control of persons at internal borders of the common European territory created a com- 
plete restructuring of all government agencies that used to work at the border (police, customs, health, transport, immigration, etc.). The Schengen process emerged from this and, following the Amsterdam and Nice treaties, the European Commission is now in a position to take the lead on immigration and asylum issues.

The arsenal of measures devised by Northern States to prevent irregular migrants from setting foot on their territories is impressive. Their precise articulation is often confidential as the whole field pertains to national security. The intergovernmental framework in which this co-operation operates ensures that it is sealed from democratic scrutiny.

This co-operation includes the following measures: imposition of visas for all refugee-producing countries, carrier sanctions, "short stop operations," training of airport or border police personnel, lists of "safe third countries," lists of "safe countries of origin," readmission agreements with neighbouring countries forming a "buffer zone," regional migration agreements, economic co-operation agreements, common databases on individual files, immigration intelligence sharing, police co-operation and interventions, criminalization of migrant smuggling, reinforced border controls, systematic detention, armed interventions on the high seas, military intervention, etc.

All these measures are aimed at preventing, directly (by a physical barrier) or indirectly (through deterrence), irregular migrants from arriving at the border, by stopping them somewhere on the way. In doing so, potential host States believe they can (and, until now, have successfully been able to) avoid triggering the control mechanisms that we have established to protect our rights and freedoms: parliamentary debates, court challenges, media scrutiny, international shaming, etc. Very often, the actual stopping of the migrant will be carried out by a third party: an employee of a private company, a foreign civil servant, etc. Very often, it will be carried out in a country where migrants' rights issues do not call for intense scrutiny.

In the public discourse, our governments do little to give the asylum seeker or the refugee a good image. On the contrary, they emphasize the negative aspects of irregular migration and play into the racism that makes many in Northern societies eager for an excuse for shutting the door on newcomers of colour. In effect, governments have succeeded in changing public opinion towards the refugee. Irregular migrations are now considered part of international organized crime and asylum seekers are not really distinguished. The events of 11 September 2001 have provided the opportunity for besmirching their reputation even further. The refugee was a very sympathetic character in the years that followed the Indochinese exodus. She is now regarded with suspicion. Is she bogus? Is she a criminal or a terrorist? If we can't know for sure, we now think that we are better to protect ourselves at the expense of the refugee. The benefit of the doubt has suddenly become a dangerous concept.

Let's give one example of the "grey zone" in which States have been operating recently. Migrant smuggling has saved many lives throughout history. Thanks to smugglers, countless people escaped Nazi Germany, Franco's Spain, Vichy France, Central Europe during the Cold War, Vietnam in the 1970s, Guatemala in the 1980s, and many other abusive regimes. The repression of migrant smuggling as it is intended to function today would not have allowed them to find protection elsewhere. In Canada, in a most recent legislative change, the smuggling of ten persons or more, without harm to persons or property, can now carry a penalty of life imprisonment: it is more than rape at gunpoint (fourteen years maximum), it is the equivalent of a crime against humanity such as genocide. Such an absurd disproportion in the scale of penalties shows how deep the fear of the much fantasized barbaric invasion is embedded in our collective mind, despite the fact that, individually, we are ready to recognize that, if we were in the shoes of many refugees, we too would use migrant smuggling to escape and protect our children from violence. This state of affairs comes partly from the fact that governments have wilfully blurred the distinction between migrant smuggling and trafficking in persons, but also results from the fact that most of the fight against migrant smuggling takes place abroad, far from the centres of interest of the majority of the population.

Legally or not, migrations will increase, because inequities are not being reduced on our planet. How much violence will we allow our States to exercise against asylum seekers in order to protect the part of collective wealth that we have appropriated for ourselves and thanks to which we have forged such instruments as democracy, human rights, and the Rule of Law? Without advocating in favour of the suppression of borders and the abolition of territorial sovereignty, can we imagine ways to regulate migration flows - perhaps through meaningful development policies - that go beyond blind repression and recognize individual human dignity? How can we combine answering migration needs and protecting human rights?

Refugees, by definition, are orphans in a system based on the States' responsibility to protect the rights of those on their territory: their own State is unable or unwilling to take up that responsibility. They need to seek the protection of another State, but while in transit seeking that protection, they fall into a gaping crack in the human rights system. States have creatively (abusively) exploited this crack through their interception measures, as we see in the fol- 
lowing papers, which go a long way towards explaining how badly our societies are coping with irregular migration flows. The challenge is immense and the principle of human rights for all everywhere seems to be the only conceptual framework that would make sense in order to "guard the guardian."

Andrew Brouwer and Judith Kumin give us a very clear picture of how interdiction mechanisms are deployed, starting with four case studies to which we might feel drawn back constantly in order to test our assumptions. They note how international law standards and principles (extraterritoriality, maritime law, responsibility, non-discrimination, non-refoulement, right to seek asylum, mobility rights, rights of the child and of the family, etc.) could be used to limit blind State repression of irregular migration flows. They then analyze the most recent UNHCR Executive Committee Conclusion no. 97 (LIV) 2003 on Protection Safeguards in Interception Measures and suggest how the future UNHCR guidelines on interception could expand on the acquis of the conclusion.

Areti Sianni exposes the complex web of measures and institutions that are being developed at the level of the European Union and notes the imbalance between deterrence and protection, the former prevailing largely over the latter. She indicates that there is some interest in creating a common set of "protected entry procedures," but deplores that the EU directive on carrier sanctions included only the "weakest of safeguards," although some airline companies have tried to fight back in courts. The externalization of immigration controls through the EU network of Member States' immigration liaison officers is also challenged in at least one national court. The international co-operation on migration issues is very active, either with many countries that form part of the buffer zone around Europe (including Albania, Morocco, Turkey, Ukraine, Yugoslavia), or countries of origin (including China, Russia, Iran), or even with regional institutions (such as Mercosur or the Andean Community).

As could be expected, considering the notoriety of the Tampa incident and of its consequences, several articles are dedicated, at least in part, to Australian immigration policies. Richard Wazana (to be published, for reasons of space, in the next issue of Refuge) offers an analysis that situates the treatment of refugees in contemporary Australia in direct line with the former "White Australia policy." $\mathrm{He}$ draws upon Lévi-Strauss's distinction between the bricoleur and the engineer to place the asylum seeker in the first category, alongside the Aboriginals and the Asian migrants of yesterday. He develops the four tropes that are "operating in Australia's media, political parties and popular culture, around refugees, border protection, generosity and
Australian culture": the belief that White and Anglo-Saxon Australian culture is under a constant and growing threat; the belief that Australia, as a nation under attack, has the right to control its borders; the belief that those seeking asylum in Australia are not refugees but are people seeking a better life, and that even if they are refugees, they are queue jumpers; the belief that Australia is generous as a recipient of refugees, thus justifying its actions of deterring the smuggling of refugees.

Jessica Howard gives us a very precise account of the Tampa incident and the policy implications of the "Pacific Solution." In line with the "whole of government approach," the sequence of the boarding and return of a "Suspected Illegal Entry Vessel" (SIEV) is detailed. The role of the Australian military and police and of IOM, chosen as lead agency over UNHCR, in the regional co-operation model with Indonesia are underlined. The Australian policy of "disruption" of people smuggling in Indonesia is analyzed and Howard delineates its consequences, including, possibly, the drowning of 353 asylum seekers (mostly women and children) with the sinking of the SIEV X (for which Australia has refused to acknowledge any responsibility). In conclusion, it is hoped that Australian policies will not prove too attractive a model for Europe or North America and that one will not witness the emergence of an "Atlantic Solution" or a "European Solution."

Jessica C. Morris compares the policies of the two countries that have successfully practiced interdiction policies on the high seas on a large scale: Australia and the U.S. She notes that interdiction is in stark contrast to the "deterritorialization" that the universal human rights doctrine had operated and emphasizes the "the lacuna between the physical spaces in which states exercise jurisdictional control and the spaces in which they will assume juridical responsibility." She underlines that "implicit to this 'teleology of restriction' is the assumption that many asylum seekers' claims are not well founded" and that, in line with a "self-diagnosed territorial vulnerability," "the goal of reasserting sovereignty clearly supersedes international responsibilities in this regard." This renewed emphasis placed on the distinction between the inside and the outside is only limited by internal factors, and especially constitutional provisions protecting human rights: the lack of a Bill of Rights in Australia and the role of executive orders in the U.S. have allowed these countries to shield their policies from judicial scrutiny. She warns against any underestimation of the forces behind restrictionist immigration controls (the doctrine of plenary power at the borders is not yet a "constitutional fossil") and asserts that the dominant interpretation by receiving States of their obligation to refugees is the "'ex gratia' approach, implying whatever 
protection is provided results purely from humanitarian goodwill."

Wendy Young and Bill Frelick offer diametrically opposed views on one potential response to U.S. interdiction of Haitians. Young argues in favour of an in-country or a regional-processing approach, with co-operation between the NGO community and American authorities. Frelick argues against such an approach, underlining that past experience has shown that in-country processing is used as a fig leaf for interdiction practices that violate the non-refoulement principle. He draws attention to the impossibly dangerous predicament facing those invited to ask for asylum while still in the country where they are persecuted.

Unfortunately, the sum total of these articles does not leave the reader with much hope of a replacement solution for interdiction in the short term. Until such time as human rights clearly prevail over any action taken by governments or in their name by private actors, inside or outside of their territory, for security purposes or otherwise, we are going to witness interdiction policies and practices that put refugees at risk, in the name of the protection of the comfort and well-being of the citizens of the North. We must debate them and, where possible, contest them.

The developments in containment policies highlight a challenge for NGOs who, at least in the case of refugee organizations, tend to be territorially based, paying most attention to refugees who reach their territory. Where governments have engaged in formal collaboration, NGOs have followed suit and developed strong cross-border ties, for example, the European NGOs responding to policy developments in the EU, or Canadian and U.S. NGOs in response to the "safe third country agreement" of 2002. However, where the collaboration is informal between governments, the NGOs have not been so effective. In the case of interdicted refugees, it is not clear that NGOs have organized themselves to make the connections.

This failure does not go unnoticed by the governments and this is surely part of the attractiveness of interdiction as the central measure to deal with refugee flows. As long as the refugees are offshore, i.e. nameless, faceless, and voiceless, there is little chance of refugees asserting legal rights or winning advocates among the local population. And when a refugee is effectively sent back to persecution, NGOs have not been good at ensuring a follow-up and publicizing their stories.

Unless a human face is given to these returnees,' their plight doesn't seem real and urgent, not even to the refugee advocates, let alone the general public. NGOs and other advocates have options open to them for providing this human face or for influencing authorities in adopting mitigating policies. All come at a cost and choices will have to be made, but strategies can be developed for effective action targeting public opinion and political elites, domestic institutions, and international organizations.

Some have been presented at a special meeting of the Canadian Council for Refugees in May 2003: direct action; presence at airports; developing research agendas; reinforcing inter-NGO co-operation, as well as co-operation between governments and NGOs; strategic and co-operative use of legal challenges; public education regarding security and refugee protection; making use of journalism and media (sharing stories of human rights abuses and interdiction stories); tracing the lives of refugees who have been interdicted.

Some policy options may also be explored with governments (one of them is discussed in the present issue): protected visas; increased access to regular migration; increased access to refugee protection in country of origin; debating the role of privatization (carriers and detention centres).

No political gain has ever been obtained without a struggle. In the end, it is left to our imagination and energies to make sure that these strategies are explored and made to bear fruit.

\section{Note}

1. See online: <http://www.web.ca/ ccr/interdictionproceedings.PDF $>$.

Janet Dench is Executive Director of the Canadian Council for Refugees.

François Crépeau is Professor of International Law at the University of Montreal; Director of the Quebec Journal of International Law; Vice-President of the Canadian Human Rights Foundation; recently Chair of the Programme Committee of the $8^{\text {th }}$ Conference of the International Association for the Study of Forced Migrations, held in Chiang Mai, Thailand, in January 2003. 